\title{
Terrorcselekmények és a magánbiztonság kapcsolatának aktuális összefüggései
}

\section{FÁBIÁN Péter ${ }^{1}$}

\begin{abstract}
Aligha túlzás azt állítani, hogy napjaink Európájában a mindennapok részévé vált a terror, és ezzel együtt újra kell gondolnunk mindazt, amit eddig a terrorcselekményekről gondoltunk. Egyre gyakoribbakká válnak az öngyilkos merénylőkröl, önmagukat pályaudvarokon, metróállomásokon felrobbantó, gépjármúvel tömegbe hajtó fanatikusokról szóló híradások. Ezek a híradások egyfelöl halálos áldozatokról, súlyosan traumatizált sérültekről szólnak, másfelöl pedig olyan terroristákról, akik végletesen elszántak, és akiket tettük elkövetésétől a büntetőjog eszközeivel lehetetlen eltántorítani.
\end{abstract}

Az elmúlt két évtized nagy tanulsága az, hogy az államok közhatalmi eszközökkel nem képesek a biztonságot szavatolni. Indokolt tehát elgondolkodni azon, hogy bevonhatók-e, és ha igen, úgy milyen körben a polgárok, a polgárok szerveződései, vagy éppen a gazdasági élet szereplői a közbiztonság fenntartásába. "Közösségi aktivitás nélkül az állam soha nem tudja betölteni a hivatását - mutat rá Németh Zsolt. ${ }^{2}$ - A közbiztonság kollektív társadalmi termék, messze nem kizárólag a rendészeti tevékenység produktuma." ${ }^{\prime 3}$

Tanulmányomban a terrorizmus fogalmát, megjelenési formáit, a terrorcselekmény büntetőjogi tényállását elemzem, majd pedig azt vizsgálom, hogy a magánbiztonság vetületében milyen kérdéseket vet fel a jelenség.

Kulcsszavak: terrorizmus, magánbiztonság

\section{A terrorizmus mibenléte}

A terrorizmus bizonyos formái már a korai társadalmakban is jelen voltak, gondoljunk csak például az ókor merénylőire, a szikarioszokra, vagy az asszaszinokra, akik a keresztes háborúk korában követtek el politikai célzattal orgyilkosságokat. A jakobinus diktatúra idején a Konvent a forradalmi terror nevében közel tizenhétezer embert végzett ki. ${ }^{4}$ A modern értelemben vett terrorizmus kialakulása azonban csak a 19. század végére tehető. ${ }^{5}$

FÁBIÁN Péter, dr., PTE Védelmi Kutatások Központ, szakértő

Péter FÁBIÁN, University of Pécs, Defence Research Centre, expert

https://orcid.org/0000-0003-0640-6557, fabianpeter@topcopgroup.com

Németh (2016) 137.

3 Németh (2016) 138.

4 Barker (2003) 13.

5 Bartkó (2011) 21-22. 
David C. Rapoport 2001-es munkájában az 1879 utáni időszakot négy szakaszra bontja, megkülönböztetve az első világháború lezárásáig tartó anarchista hullámot, az 1960-as évek végéig tartó antikolonialista, illetve az 1979-ben kifulladó új baloldali hullámot, végül pedig a - lényegében napjainkban is létező - vallási hullámot. ${ }^{6}$ Más források aszerint tipizálnak, hogy az egyes terrorszervezetek milyen ideológia alapján múködnek. A „represszív” terrorista csoportok jellemzően olyan országokban működnek, amelyekben elvileg már adott minden polgár számára a jogegyenlőség, ám ezek a csoportosulások éppen a jogegyenlőtlenséget igyekeznek fenntartani erőszakos eszközökkel. Példaként az Amerikai Egyesült Államokban müködő Klu-Klux-Klan említhető. A „lázadó” terrorista csoportok szélsőségesen nacionalista, szeparatista célokból hajtanak végre merényleteket saját országukban. Ilyenek például a baszk ETA, Észak-Írországban az IRA, Srí Lankán a Tamil Tigrisek, vagy éppen a csecsenek. A „társadalomforradalmi” terrorizmus képviselői számára - mint amilyen például a német Baader-Meinhof-csoport is volt - az ideált a marxi proletárforradalom jelentette, öngyilkos akcióikkal a kommunizmus eljövetelét sürgették. ${ }^{7}$

A terrorizmus mibenlétének feltárása nem könnyű feladat, és az erre irányuló kísérletek is rendszerint csak a főbb ismérvek meghatározásáig jutnak el. A helyzetet tovább bonyolítja, hogy mindazt, amit korábban a terrorizmusról gondoltunk, a 2001. szeptember 11-én történtek felülírták.

A terrorizmusról való diskurzust különösképpen megnehezíti egy felvetés, amely első olvasatra talán meglepő: lehet, hogy maguk a terroristák is áldozatok? Hiszen ők olyannyira hisznek valamiben, hogy azért az életüket is hajlandók feláldozni. Vagy más megközelítésben: vajon tekinthetők-e hősöknek a terroristák? Az az ügy ugyanis, amelynek érdekében cselekednek, egy nép, egy népcsoport számára élet-halál kérdése lehet. Szokás idézni az „aki nekem terrorista, az neked szabadságharcos” aforizmát, utalva ezzel arra, hogy hajlamosak vagyunk terroristának bélyegezni azt, akinek az ügyével nem értünk egyet. ${ }^{8}$ A nácik például a hazájuk német megszállása ellen küzdő ellenállási csoportokat terroristáknak tartották. Az 1972. évi müncheni olimpiai mészárlást követően tartott ENSZ közgyúlésen pedig a tagállamok egy kisebb csoportja arra hivatkozva vétózta meg a nemzetközi fellépést célzó határozatot, hogy „azoknak a népeknek, amelyek azért küzdenek, hogy felszabadítsák magukat az idegen elnyomás alól, joguk van az erőszakot is beleértve minden, rendelkezésükre álló módszert alkalmazni". 9

Kérdés ugyanakkor, hogy lehet-e a politikai racionalitás szemszögéből vizsgálni egy olyan tettet, amelynek célja az ölés és az elrettentés, és amely az áldozatok oldalán „könnyeket, kiabálást, ökölrázást, álmatlanságot és lidércálmokat vált ki”. ${ }^{10}$ Boaz Ganor izraeli szakértő éppen ebből a megfontolásból hangsúlyozza, hogy külön kell

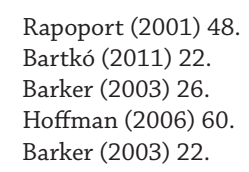


választani a terrorizmus lélektani és társadalmi hátterére fókuszáló, az áldozatot a középpontba helyező vizsgálódásokat azoktól, amelyek egyfajta politikai eszközt látnak a terrorcselekményekben. ${ }^{11}$

\section{A terrorizmus fogalma}

A terrorizmus tehát egy erkölcsi dilemmákat felvető, politikailag érzékeny téma. A Reuters és még néhány más hírügynökség sokáig nem is volt hajlandó használni a „terrorizmus” kifejezést, mondván, ez pusztán „morális címkézés” lenne. ${ }^{12}$ A definíciótól azonban nem tekinthetünk el, ennek hiánya akadályozná a terrorista cselekedetek elemzését. A fogalom meghatározására többen is vállalkoztak, mind politikatudományi, mind jogi szempontokat alapul véve.

Boaz Ganor definíciója a civil célpontok ellen irányuló, de legalábbis azokat fenyegető erőszakot, a politikai, ideológiai hátteret emeli ki, és a terrorizmus céljaként pedig a társadalmi, gazdasági, kormányzati stabilitás megingatását jelöli meg. ${ }^{13}$ Ben Saul szerint a terrorcselekmény minden esetben egy erőszakos, emberélet kioltására, de legalábbis veszélyeztetésére irányuló cselekményben ölt testet, amely cselekmény elkövetője politikai, ideológiai, vallási indíttatásból cselekszik, tettét fegyveres konfliktuson kívül valósítja meg, legfőbb célja pedig az, hogy félelmet keltsen a társadalomban, vagy annak egy részében. ${ }^{14} \mathrm{Az}$ Amerikai Egyesült Államok Szövetségi Nyomozóirodája (FBI) a terrorizmus lélektani hatását hangsúlyozza, olyan erőszak törvénytelen alkalmazását értve a fogalom alatt, amely személyek vagy tulajdon ellen irányul, és amelynek célja „egy kormány, a civil lakosság, vagy a lakosság bármely szegmensének megfélemlítése vagy kényszerítése politikai vagy társadalmi célok előmozdítása érdekében" ${ }^{15}$

A fentiekben a politikatudományi megközelítést vizsgálva láthattuk, hogy a különböző szerzők rendszerint három szükségképpeni elemet azonosítanak, ezek az erőszak alkalmazása, a félelemkeltés, valamint a politikai célok. ${ }^{16}$

A jogi (nemzetközi jogi, illetve büntetőjogi) források értelemszerűen ennél egzaktabb meghatározásra törekednek. A robbantásos terrorizmus visszaszorításáról szóló 1997. évi ENSZ Egyezmény 2. cikke értelmében „bűncselekményt követ el az a személy, aki jogellenesen és szándékosan robbanó vagy más halált okozó eszközt visz be vagy helyez el közhasználatú helyen, állami vagy kormánylétesítményben, közforgalmú tömegközlekedési üzemben vagy közérdekű üzemben, illetve az azok elleni támadás során vagy azokban ilyen eszközt elsüt vagy felrobbant”, és teszi mindezt „azzal

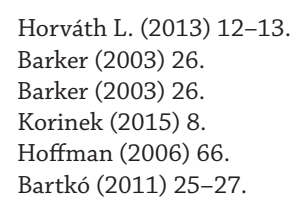


a szándékkal, hogy halált vagy súlyos testi sértést okozzon”, vagy „az adott helyet, létesítményt vagy üzemet súlyosan megrongálja”. ${ }^{17}$

Az Európai Unió Tanácsának a terrorizmus elleni küzdelemről szóló 2002/475/IB számú kerethatározata azon büntetendő magatartások terrorista cselekményként történő megjelölését várja el a tagállamoktól, amelyek az elkövetés módja vagy az összefüggések miatt károsíthatnak valamely államot vagy nemzetközi szervezetet, és amely cselekmények célja az, hogy a lakosságot „komolyan megfélemlítsék”, állami szervet vagy nemzetközi szervezetet cselekvésre vagy attól való tartózkodásra kényszerítsenek, az állam vagy a nemzetközi szervezet alapvető rendjét „súlyosan megzavarják vagy lerombolják". ${ }^{18}$

\section{Terrorcselekmény a magyar büntetőjogban}

Magyarországon 1971-től kezdődően került sor több, a témába vágó nemzetközi egyezmény kihirdetésére, a terrorcselekmény tényállását pedig az 1978. évi Btk. tartalmazta először. A 261. §-ban írt elkövetési magatartás az emberrablás és a zsarolás elemeit ötvözte, nem határozott meg ugyanakkor speciális - politikai, ideológiai - célzatot. ${ }^{19}$ A 2001. szeptember 11-i események hatására fogadta el az Országgyúlés a Btk.-t és egy sor más jogszabályt módosító 2001. évi LXXXIII. törvényt. ${ }^{20}$ Ekkor bővítették ki a terrorcselekmény tényállását egy új elkövetési magatartással, büntetendővé nyilvánítva ezáltal azt is, ha valaki „anyagi eszközöket szolgáltat” a terrorcselekmény elkövetéséhez. ${ }^{21}$

2002-ben további két ENSZ-egyezményt hirdettek ki, az egyik a robbantásos terrorizmus visszaszorításáról szóló 1997. évi, a másik pedig a terrorizmus finanszírozásának visszaszorításáról szóló 1999. évi ENSZ-egyezmény volt. ${ }^{22}$ Mindezeket követően, 2003-ban módosították az 1978. évi Btk.-t, immár a nemzetközi elvárásokhoz igazítva a terrorcselekmény tényállását. A módosítás folytán egy delictum complexum jött létre, amely tartalmazta egyrészt a klasszikus terrorista tényállást, másrészt pedig bizonyos köztörvényes bűncselekményeket sorolt fel, amelyek a Btk. 261. § szerint büntetendők, ha azokat terrorista célból követték el. Később még két ízben módosították a büntető törvényt. 2007-ben az 1999. évi ENSZ-egyezményben írtak szerint pönalizálták az olyan finanszírozási jellegú cselekményeket, amelyeket egyénileg, nem például egy

\footnotetext{
2002. évi XXV. törvény a robbantásos terrorizmus visszaszorításáról, New Yorkban, az Egyesült Nemzetek Közgyülésének 52. ülésszakán, 1997. december 15-én elfogadott nemzetközi egyezmény kihirdetéséről. 2. cikk.

18 A Tanács kerethatározata (2002. június 13.) a terrorizmus elleni küzdelemről (2002/475/IB). 1. cikk (1) bekezdés.

19 Bartkó (2011) 211.

20 Belovics et al. (2012) 471.

21 1978. évi IV. törvény a Büntető Törvénykönyvről (1978. évi Btk.) 261. § (1) bekezdés 2001. évi LXXXIII. törvénymódosítással bevezetett szövegváltozata.

22 2002. évi XXV. törvény a robbantásos terrorizmus visszaszorításáról 1997. december 15-én New Yorkban elfogadott ENSZ-egyezmény kihirdetéséről; 2002. évi LIX. törvény a terrorizmus finanszírozásának visszaszorításáról szóló 1999. december 9-én New Yorkban elfogadott ENSZ-egyezmény kihirdetéséről.
} 
terrorista csoport tagjaként hajtottak végre. ${ }^{23}$ 2009-ben pedig a büntetési tételt szigorították, tizenöt évről húszra emelték annak felső határát. ${ }^{24}$

A hatályos Btk. - szakítva a korábbi megoldással - több különálló tényállást alkotva, külön szakaszokba foglalva nyilvánítja büntetendővé a terrorcselekményt, a cselekmény feljelentésének elmulasztását, és a terrorizmus finanszírozásának büntettét. ${ }^{25}$ A jogalkotó a terrorcselekmény pönalizálásával a közbiztonsághoz, az államok, állami szervek, nemzetközi szervezetek zavarmentes működéséhez, a polgárok szabad és félelemtől mentes életéhez füződő közérdeket kívánja védelmezni. ${ }^{26}$

A Btk. 314. § (1) bekezdésében írt büntett tettese az, aki a törvényben részletesen „meghatározott személy elleni erőszakos, közveszélyt okozó vagy fegyverrel kapcsolatos bűncselekményt követ el”, és ezt azzal a célzattal teszi, hogy a) állami szervet, más államot, nemzetközi szervezetet kényszerítsen, b) a lakosságot megfélemlítse, c) más állam vagy nemzetközi szervezet alapvető müködését megzavarja. ${ }^{27}$ Ugyancsak terrorcselekményért vonható felelősségre a terrorcsoport szervezője, valamint az, aki „jelentős anyagi javakat kerít hatalmába”, és azok visszaadását, sértetlenül hagyását attól teszi függővé, hogy állami szervhez, nemzetközi szervezethez intézett követelését teljesítik-e. ${ }^{28}$ Végül, a Btk. 316. §-ban írt terrorcselekményt követi el az, aki terrorcselekmény elkövetésével fenyeget, illetve az is, aki azért utazik ki az ország területéről, vagy azért utazik azon át, hogy csatlakozzon egy terrorista csoporthoz. ${ }^{29}$

\section{A terrorizmus kriminológiai értelmezése}

A terrorizmus „értelmezhető és kezelhető” a büntetőjog intézményrendszerén belül. ${ }^{30}$ Az azonban meglehetősen nyomasztó megállapítás, hogy a terrorista, különösen pedig a magányos terrorista ellen fellépni a büntetőjog eszközeivel nem lehetséges. Egyes szerzők szerint létezik valamiféle „terrorista személyiség”, és ebben a megközelítésben a terrorista cselekményre való hajlandóság elsődlegesen alkati kérdés, amely agresszióra való hajlamban nyilvánul meg. ${ }^{31}$

A biológiai elméletek szerint az, hogy a terrorista magatartását különféle hormonális és neurokémiai folyamatok befolyásolják, szervezetükben túlteng az endorfin, az acetilkolin és a noradrenalin. Ez utóbbi ingerületátvivő vegyület, az erek szűkítésével fokozza a vérnyomást, az acetolin az izgatottság nyomán fellépő információt

\footnotetext{
2007. évi XXVII. törvény a Büntető Törvénykönyvről szóló 1978. évi IV. törvény és más büntetőjogi tárgyú törvények módosításáról.

24 2009. évi LXXX. törvény a Büntető Törvénykönyvről szóló 1978. évi IV. törvény módosításáról.

25 2012. évi C. törvény a Büntető Törvénykönyvről 314-316. §, 317. §, 318. §

26 Belovics et al. (2012) 472.

27 Btk. 314. § (1) bekezdés.

28 Btk. 314. § (2) bekezdés.

29 Btk. 316. §.

30 Korinek (2015) 11.

31 Korinek (2015) 11.
} 
juttatja el az idegektől az izmokig, az endorfin pedig a fájdalomcsillapításért és a boldogságérzetért felel. ${ }^{32}$

A terrorizmust a pszichológiai elméletei „lelki deformációként” határozzák meg. A freudi alapokon nyugvó ösztönelméleti iskola képviselői úgy vélik, hogy az agreszszió nem más, mint egy, a külvilág felé irányuló „halálvágy”. Az ösztönös agresszivitás elmélete szerint az agresszív tett végrehajtása kielégülést okoz az elkövető számára. A frusztráció/agresszió elmélete az egyéni kudarcok kompenzálását látja az agresszióban. ${ }^{33}$ a nemzedéki konfliktusok elmélete kora gyermekkori frusztrációt, abúzust vél felfedezni a terrorista cselekmények hátterében, a nárcizmus elmélete szerint pedig a terrorista súlyos önértékelési zavarokban szenved, és úgy kompenzál, hogy „az áldozat szerepéből átlép a morális elvek nevében cselekvő agresszor szerepébe”. ${ }^{34}$

Egyet kell értenünk Korinek László álláspontjával, sem a biológiai, sem a pszichológiai elméletek nem fogadhatók el, különösképpen pedig nem menthetnek fel senkit tettei következményei alól a torzult személyiségjegyek. ${ }^{35}$ A terrorizmus okait kutató elméletek tanulmányozása azonban nem tekinthető hiábavalónak, főként nem napjainkban, a magányos terroristák korában.

Az 1960-as évek forradalmi és ellenállási mozgalmakból kinőtt terrorizmusa már használta a modern technikát. A terroristák legfőbb módszere a bombarobbantás volt, a levélbomba pedig nagyhatású újításnak számított. Idővel az emberrablás és az orvgyilkosság is egyre népszerúbb lett. Az 1960-as évek végén a repülőgép-eltérítések száma szaporodott meg. 1972 mérföldkőnek számít a terrorizmus történetében. Előbb a tel-avivi repülőtéren került sor merényletre, a Palesztin Felszabadítási Fronttal szövetséges Japán Vörös Hadsereg három katonája az Egyesült Államokból érkező utasokra támadt, huszonöten meghaltak, hetvenhatan megsebesültek. Ezt követte 1972 szeptemberében a müncheni túszejtő terrorakció, amelyet a szakirodalom „barikád és túsz" típusú eseményként tart számon: a Fekete Szeptember nevü csoport foglyul ejtette az izraeli olimpiai csapat tagjait. A rendőrök tűzpárbajba keveredtek a terroristákkal, a körülmények szerencsétlen alakulása folytán minden túsz meghalt, és három kivételével valamennyi túszejtő is. ${ }^{36} \mathrm{~A}$ korszak terroristáinak még nem igazán volt egységes ideológiájuk, a módszerek és eszközök leginkább utánzás révén terjedtek, az akciók egymástól elszigetelt jelenségeknek tűntek. A célok vagy konkrétak voltak, például a bebörtönzött bajtársak szabadon engedését akarták elérni, vagy csak provokálni akarták a kormányokat, hogy azok „túlreagálják az ügyet”. ${ }^{37}$

A terrortámadások az 1970-es évektől egyre látványosabbak, a szándék a minél nagyobb pusztításra irányult. A repülőgép-eltérítéseket felváltották a repülőgépek elleni bombatámadások. 1985-ben az Air India egyik járata ellen intézett támadásban 329-en

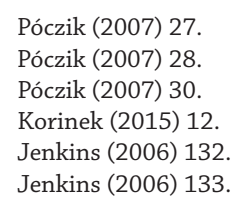


haltak meg, 1988-ban a PanAm járata elleni merénylet 270 halálos áldozatot követelt. Megnövekedett a pályaudvarokon végrehajtott bombarobbantások száma. A terrorista csoportok egyre gyakrabban követtek el összehangolt múveleteket, 1995-ben például egyazon napon tizenkét amerikai utasszállító repülőgép ellen terveztek merényletet; ha az akció nem hiúsul meg, több ezer utas válhatott volna áldozattá. A vallási fanatikusok által elkövetett akciók az 1990-es évek második felétől váltak egyre gyakoribbakká. 1996-ban iszlám szélsőségesek autóbombával belehajtottak egy amerikai katonai lakóépületbe, tizenkilencen meghaltak, háromszáznál is többen megsebesültek. 1998ban az al-Káida harcosai - ugyancsak autóbombákkal - a tanzániai és a kenyai amerikai nagykövetség ellen hajtottak végre támadást. ${ }^{38}$

A 20. század utolsó éveinek terrortámadásai egyre véresebbek, szándékoltan egyre több az áldozat. A szakirodalom „új terrorizmusról” beszél. A terroristákat a vallási fanatizmus hajtja, istenük nevében lépnek fel, „meg vannak győződve, hogy Istennek tetsző dolgot cselekszenek, ezért kevésbé tartanak [...] a földi törvényektől”. ${ }^{39}$ Ez a folyamat a New York-i ikertornyok, illetve a Pentagon elleni támadásban csúcsosodott ki. Közel háromezer ember halt meg, és ha arra gondolunk, hogy az összedőlő épületekből mintegy huszonötezer ember tudott elmenekülni, könnyen beláthatjuk, hogy a terroristák célja még az ennél is nagyobb pusztítás volt.

Napjainkban azonban újabb változásoknak vagyunk tanúi. A szervezett, sok embert mozgató terrorakciók helyett, úgy tűnik, eljött a magányos terroristák ideje. 2015. január 7-én a párizsi szatirikus lap, a Charlie Hebdo szerkesztősége ellen hajtott végre terrortámadást két felfegyverkezett dzsihadista, az akció során 20-an haltak meg, köztük a támadók is. ${ }^{40}$ 2015. március 18-án a tuniszi Bardo Múzeumban három iszlám terrorista tüzet nyitott a turistákra, a halálos áldozatok száma 22 volt, és a támadók is meghaltak. ${ }^{41}$ 2015. november 13-án összehangolt akciók keretében hajtottak végre fegyveres támadást terroristák Párizs több pontján, így például a Bataclan színházban is, ahol utóbb tűzpárbajba keveredtek a rendőrökkel. A halálos áldozatok száma 120, ebből 89-en a Bataclan színháznál vesztették életüket. Nyolc terrorista is meghalt. ${ }^{42}$ 2016. március 22-én Brüsszel három különböző pontján (a nemzetközi repülőtéren két helyen, és a Maelbeek metróállomáson) hajtottak végre robbantásos merényletet iszlamista terroristák. 32-en meghaltak, elhunyt a három elkövető is. Az akciót az Iszlám Állam magára vállalta. ${ }^{43}$ 2016. július 14-én Nizzában, a tengerparti sétányon a nemzeti ünnep alkalmából felvonuló tömegbe hajtott egy bérelt teherautóval egy tunéziai

38 Jenkins (2006) 134-135.

39 Jenkins (2006) 136.

40 Három nap terror Franciaországban. 2015. 01. 09. Forrás: http://index.hu/kulfold/2015/01/10/terror_parizsban_ osszefoglalo/ (2017. 12. 13.).

41 Gunmen storm Tunisian museum, kill 17 foreign tourists. 2015. 03. 18. Forrás: www.reuters.com/article/us-tunisiasecurity-idUSKBNOP61F020150626 (2017. 12. 13.).

42 Paris attacks kill more than 120 people - as it happened. 2015.11. 14. Forrás: www.theguardian.com/world/live/2015/ nov/13/shootings-reported-in-eastern-paris-live (2017. 12. 13.).

$43 \quad$ Isis supporters claim group responsible for Brussels attacks: 'We have come to you with slaughter'. 2016. 03.22. Forrás: www.independent.co.uk/news/world/europe/isis-supporters-claim-responsibility-for-brussels-attacks-bombings-belgium-airport-maalbeek-metro-we-a6945886.html (2017. 12. 13.). 
származású nizzai lakos. A halálos áldozatok száma 84, több mint 200-an súlyosan megsebesültek. Az elkövetőt a rendőrök lőtték le. A merényletet szintén az Iszlám Állam vállalta magára. ${ }^{44}$

A fenti kiragadott példák jól mutatják a terrorista módszerek újszerű voltát. Napjainkban fő célpontnak egyre inkább a szabadtéri rendezvények, a koncertek, a turisták által látogatott események számítanak, ezek közös jellemzője az, hogy nagy tömegeket vonzanak és legtöbb esetben magánbiztonsági szempontból is relevanciával bírnak. Ez annál is inkább fontos kérdés, mert úgy tûnik, „a terroristák köztünk élnek”. Sok terrortámadás után arról számol be a sajtó, hogy az elkövetőnek még a közvetlen hozzátartozói sem sejtették, hogy rokonuk mire készül. ${ }^{45}$

\section{A magánbiztonság fogalma}

A magánbiztonság - Kacziba Antal definíciója szerint - „olyan kívánatos jogállapot, amelyben a személy és a jogi személy a magánjogban kifejeződő szabadságjogainak, gazdasági, szociális és kulturális jogainak egyenjogúsága, valamint jogos érdekeinek érvényesülése szavatolt". ${ }^{46}$

A polgári demokratikus jogállamok elismerik az állam erőszak-monopóliumát, és azt a közrend, a közbiztonság fenntartása érdekében alkalmazhatónak tartják. Közbiztonság és magánbiztonság nem egymás ellentettjei, nem is határolhatók el mereven egymástól, gyakran kerülnek átfedésbe, a kívánatos pedig az, ha sikerül együttmúködést kialakítani közöttük. ${ }^{47} \mathrm{~A}$ jogalkotó szándéka szerint - miként az a személy- és vagyonvédelmi, magánnyomozói tevékenység szabályairól szóló 2005. évi CXXXIII. törvény preambulumában írtakból kiderül - a magánbiztonság körébe eső „olyan szolgáltatások, amelyek az egyén személyhez füződő jogainak hatékonyabb védelme révén a közrend, közbiztonság fenntartásához járulnak hozzá" ${ }^{48}$

A kormányok, a döntéshozók egyre inkább kénytelenek belátni, hogy közhatalmi eszközökkel nem képesek a polgárok biztonságát az élet minden területén garantálni, célravezetőbb és az esetek jelentős részében költséghatékonyabb, ha bizonyos tevékenységeket - az állam rendészeti monopóliumának érintetlenül hagyása mellett - kiszerveznek. A nemzetközi trend tehát az, hogy a háttértevékenységek egyre szélesebb körét illetően biztosít lehetőséget az állam arra, hogy a természetes és jogi személyek piaci viszonyok között vásárolhassák meg a magánbiztonság nyújtását vállaló cégek szolgáltatásait. Ennek ellenére azonban a magánbiztonság szakirodalma még jelenleg

\footnotetext{
44 Attentat de Nice : ce que l'on sait, deux jours après. 2016. 07. 16. Forrás: www.lemonde.fr/societe/article/2016/07/16/1-organisation-etat-islamique-revendique-l-attentat-de-nice_4970604_3224.html (2017. 12.13.).

45 A New York Times szakértője szerint egyre hihetőbb, hogy Stephen Paddock az Iszlám Állam terroristája lehetett. 2017. 10. 05. Forrás: https://444.hu/2017/10/05/a-new-york-times-szakertoje-szerint-egyre-hihetobb-hogy-stephen-paddock-az-iszlam-allam-terroristaja-lehetett (2017. 12. 13.).

46 Kacziba (2013) 33-34.

47 Christián (2014a) 16.

48 Christián (2014b) 26.
} 
is igen gyér, „egy meglehetősen vitatott, tudományos alapossággal kevéssé kimunkált jogterületről van szó”. ${ }^{49}$

A magánbiztonság alkotmányos alapját az Alaptörvény V. cikkében találjuk, eszerint „mindenkinek joga van törvényben meghatározottak szerint a személye, illetve a tulajdona ellen intézett vagy az ezeket közvetlenül fenyegető jogtalan támadás elhárításához" ${ }^{50}$ A magánbiztonság létének azonban van egy további előfeltétele is - mutat rá Christián László - ez pedig nem más, mint a magánbiztonság iránti piaci igény. ${ }^{51}$ A szervezeti feltételeket a személy-, vagyonvédelmi és magánnyomozói kamaráról szóló 1998. évi IV. törvény teremtette meg azáltal, hogy lehetővé tette a magántulajdon védelmére szolgáló, vagyis magánbiztonsági vállalkozások alapítását. Szükséges ugyanakkor leszögezni, hogy a magánbiztonsági vállalkozások nem rendelkeznek sem az állami rendészet jogosítványaival, sem annak eszköztárával. Bár múködésük felett a rendőrség kontrollt gyakorol, ám tevékenységüket a megbízóval kötött polgári jogi szerződés alapján látják el, jogosultságaik nem terjeszkedhetnek túl azokon a jogosítványokon, amelyekkel megbízójuk rendelkezik. ${ }^{52}$

\section{Következtetések és összegzés}

A közbiztonság garantálása mindenkor az állam feladata, rendészeti jogosítványok és eszközök széles tárháza áll a rendelkezésére, optimális esetben képes a közhatalmi szervei közötti hatékony együttműködést megszervezni. Azonban éppen a terrorista cselekmények kapcsán jutunk arra az elkeserítő következtetésre, hogy az állam nem minden esetben képes eleget tenni ezeknek az elvárásoknak.

Több esetben arról szólnak a hírek, hogy bár a terrorista akciót elkövető személy már korábban a hatóságok érdeklődésének homlokterébe került, ám vagy az információfeldolgozás elégtelen volta, vagy a különböző szervek (rendőrség, nemzetbiztonság) közötti információáramlás hiánya, netán a különböző szervek közötti rivalizálás eredményeként senki nem akadályozta meg a terve végrehajtásában. Ez a körülmény pedig felveti a kérdést: a magánbiztonsági vállalkozások mennyiben jelenthetnek segítséget a terrorizmus elleni küzdelemben?

A fentiekben egyrészt azt állapítottuk meg, hogy a napjaink terroristái rejtőzködő életmódot folytatnak, kifelé sok esetben a törvénytisztelő állampolgár képét mutatják, de legalábbis kerülik a hatóságok figyelmét. Vagy teljesen magányosan készítik elő tettüket, vagy az interneten, különféle, a hatóságok által egykönnyen fel nem tárható csatornákon keresztül tartják a kapcsolatot ideológiai vezetőikkel, esetleges társaikkal. A másik megállapításunk az volt, hogy az új típusú terroristák (vallási) fanatikusok, nemcsak számítanak arra, hogy az akcióban meghalhatnak, hanem haláluk kifejezetten része a tervüknek. A harmadik fontos körülmény pedig, amelyre felhívtuk

\footnotetext{
49 Christián (2014a) 22.

50 Magyarország Alaptörvénye, V. cikk

51 Christián (2014a) 22.

52 Christián (2014a) 22.
} 
a figyelmet, a terrorista célpontok jellegzetessége: a terroristák előszeretettel hajtják végre tettüket tömegrendezvényeken, turisták által kedvelt helyeken.

Az Amerikai Egyesült Államokban 2001. szeptember 11. után fogadták el a Patriot Actet, amely széles körben megteremtette a rendészeti szervek és a magánbiztonsági vállalkozások együttműködésének alapjait. A Clinton-adminisztráció idején lehetővé tették a magánszektor bevonását a közrend védelmével kapcsolatos feladatokba. 1997-ben pedig felállították a Kritikus Infrastruktúrák Védelméért Felelős Bizottságot, amely az információs technológia körében koordinálta a magánbiztonsági cégeknek a védelmi feladatokba történő bevonását. ${ }^{53}$

A nemzetközi szakirodalomban találkozhatunk a plural policing kifejezéssel, amely arra utal, hogy a rendőrség és a magánbiztonság egyformán része a rendészetnek, céljaik és eszközeik különbözősége meghatározó. ${ }^{54}$ Miként arról a korábbiakban már volt szó, a magánbiztonság szereplői a megbízóval kötött polgári jogi szerződés alapján múködnek, a megbízó érdekében, a megbízó által adott utasítások alapján, tevékenységük ügyfél- és profitorientált. Külhoni szerzők nem mulasztják el felhívni a figyelmet arra, hogy (részben éppen a fentebb felsorolt körülmények miatt) a magánbiztonság bevonása a rendészeti feladatok ellátásába meglehetős kockázatokkal jár. Így például, a tapasztalatok azt mutatják, hogy a magánszektor nem keresi a rendészeti szervekkel való együttmüködést, nem ritkán kifejezetten feszült a közöttük lévő viszony. Kockázatokat rejthet magában az, hogy a magánbiztonságban foglalkoztatott személyek képzettsége jellemzően alacsony színvonalú, kommunikációs képességük nem minden esetben kifogástalan, konfliktuskezelési technikáik olykor egysíkúak, mindezeknek köszönhetően pedig az állampolgárok körében nem örvendenek különösebb megbecsültségnek. Az elemzők a korrupciót is a lehetséges veszélyek között említik, miként az éles piaci versenyt is. ${ }^{55}$

Biztonság alatt legáltalánosabb értelemben az „állam által biztosítandó fizikai biztonságot” értjük, ám az, hogy a részleteket illetően mit gondolunk e fogalomról, nagyban függ attól, hogy miként értékeljük a fizikai biztonság és a jogbiztonság (vagy inkább jogállamiság és a szabadságjogok) viszonyát. ${ }^{56}$ Amikor azt a kérdést vizsgáljuk, hogy az állam milyen eszközöket alkalmazhat a biztonság megteremtése érdekében, in concreto a terrorizmus elleni küzdelem során, akkor felmerül egy dilemma. „A dilemmát - magyarázza Jakab András - az a konfliktus jelenti, amely a visszaéléstől való félelem (ezt fejezi ki a jogban a jogállamiság fogalma) és a hatékonyság (a fent vázolt biztonsági probléma kezelése) között áll fenn." ${ }^{57}$ A magyar Alkotmánybíróság több határozatában is egyértelművé tette, hogy az alapjogok korlátozására csak más szabadságjogok védelme vagy egyéb alkotmányos cél érdekében kerülhet sor, a korlátozásnak ki kell állnia a szükségesség és arányosság tesztjét, az alkalmazott eszköz pedig csakis




a cél elérésére alkalmas legenyhébb eszköz lehet. ${ }^{58}$ Álláspontom tehát egyrészt az, hogy a terrorizmus elleni harcra - bármilyen nagy is a veszély - csakis ezen alkotmányos kereteken belül van lehetőség. Másrészt meggyőződésem, hogy a terrorizmus elleni fellépés sem legitimálja az emberi méltóságot sértő, az emberi jogokat és szabadságokat csorbító megoldásokat. Osztom a Rasszizmus és Intolerancia Elleni Európai Bizottság (European Commission against Racism and Intolerance, ECRI) 2001 szeptembere után közzétett nyilatkozatában megjelenő álláspontot, amely szerint minden lehetséges eszközzel fel kell lépni a terrorizmussal szemben, illetve a terrorcselekmények megelőzése érdekében, ám „a terrorizmussal szembeni küzdelem nem válhat ürüggyé a rasszizmus, a faji diszkrimináció és az intolerancia megengedéséhez" ${ }^{59}$

Amennyiben tehát elfogadjuk, hogy az állam szervei által folytatott terrorellenes küzdelem csak a legszigorúbb eljárási garanciák mellett folyhat, úgy felvetődik a kérdés: a magánbiztonság szervei bevonhatók-e ebbe a küzdelembe? Megítélésem szerint megnyugtató választ e kérdésre csak jogalkotói szinten lehet adni.

\section{IRODALOMJEGYZÉK}

Barker, Jonathan (2003): A terrorizmus. Budapest, HVG Kiadói Rt.

Bartkó Róbert (2011): A terrorizmus elleni küzdelem kriminálpolitikai kérdései. Győr, Universitas-Győr Nonprofit Kft.

Belovics Ervin - Molnár Gábor Miklós - Sinku Pál (2012): Büntetöjog II. a 2012. évi C. törvény alapján. Budapest, HVG-Orac Kiadó.

Christián László (2014a): A magánbiztonság elméleti alapjai. Budapest, Nemzeti Közszolgálati Egyetem Rendészettudományi Kar.

Christián László (2014b): A magánbiztonság megközelítésének egyes aspektusai. Pro Publico Bono - Magyar Közigazgatás, 4. sz. 21-30. Forrás: http://uni-nke.hu/uploads/media_items/a-maganbiztonsag-megkozelitesenek-egyes-aspektusai.original.pdf (2017. 12. 13.).

Christián László (2015): A magánbiztonság aktuális nemzetközi trendjei, rövid hazai helyzetértékeléssel. In Gál Gyula - Hautzinger Zoltán szerk.: Pécsi Határör Tudományos közlemények, XVI. 57-63. Forrás: www.pecshor.hu/periodika/XVI/christian.pdf (2017. 12. 13.)

Garamvölgyi Orsolya (2005): Az ECRI általános politikai ajánlása a terrorizmus elleni harc során megvalósuló rasszizmus elleni küzdelemről. Collega, 9. évf. 2. sz. 187-190.

Hoffman, Bruce (2006): A terrorizmus belülről. In Tálas Péter szerk.: A terrorizmus anatómiája. Budapest, Zrínyi Kiadó. 43-71.

Horváth L. Attila (2013): A terrorizmus csapdájában. Budapest, Zrínyi Kiadó.

Jakab András (2014): Jogállamiság és terrorfenyegetés. Az alkotmány normativitásának és az életmentő kínzás megengedhetőségének kérdése. In: A világ mi magunk vagyunk...: Liber Amicorum Imre Vörös. Budapest, HVG-Orac Lap- és Könyvkiadó Kft. 240-262. Forrás: http://jog.tk.mta.hu/ uploads/files/Koenyvek/A_vilag_mi_magunk_vagyunk.pdf (2017.12. 13.)

Jenkins, Brian Michael (2006): Amerika válasza a terrorizmusra és ennek hatása a transzatlanti viszonyokra. In Tálas Péter szerk.: A terrorizmus anatómiája. Budapest, Zrínyi Kiadó. 131-154.

Kacziba Antal (2013): Közrend, magánrend, közbiztonság. In Gál Gyula - Hautzinger Zoltán szerk.: Pécsi Határör Tudományos Közlemények, XIV. 23-36.

\footnotetext{
58 30/1990. (XII. 15.) AB határozat.

59 Garamvölgyi (2005) 188.
} 
Korinek László (2015): A terrorizmus. Belügyi Szemle, 63. évf. 7-8. sz. 7-38.

Németh Zsolt (2016): A civil szféra a közbiztonságban. In: Ünnepi kötet Vavró István professzor 80. születésnapjára. Magyar Statisztikai Társaság - Széchenyi István Egyetem Deák Ferenc Állam- és Jogtudományi Kar. 137-147.

Póczik Szilveszter (2007): A terrorizmus biológiai és pszichológiai elméletei. Világosság, 48. évf. 5. sz. 25-41.

Rapoport, David C. (2001): The International World As Some Terrorists Have Seen It: A Look at a Century of Memoires. In Rapoport, David C. szerk.: Inside Terrorist Organizations. London - Portland, Oregon, Frank Cass. 32-58.

\section{Internetes források}

Három nap terror Franciaországban. 2015. 01. 09. Forrás: http://index.hu/kulfold/2015/01/10/terror_parizsban_osszefoglalo/ (2017. 12. 13.)

Gunmen storm Tunisian museum, kill 17 foreign tourists. 2015. 03. 18. Forrás: www.reuters.com/ article/us-tunisia-security-idUSKBNOP61F020150626 (2017. 12. 13.)

Paris attacks kill more than 120 people - as it happened. 2015. 11. 14. Forrás: www.theguardian.com/ world/live/2015/nov/13/shootings-reported-in-eastern-paris-live (2017. 12. 13.)

Isis supporters claim group responsible for Brussels attacks: 'We have come to you with slaughter'. 2016. 03. 22. Forrás: www.independent.co.uk/news/world/europe/isis-supporters-claim-responsibility-for-brussels-attacks-bombings-belgium-airport-maalbeek-metro-we-a6945886.html (2017. 12.13.)

Attentat de Nice: ce que l’on sait, deux jours après. 2016. 07. 16. Forrás: www.lemonde.fr/societe/article/2016/07/16/1-organisation-etat-islamique-revendique-l-attentat-de-nice_4970604_3224. html (2017. 12. 13.)

A New York Times szakértője szerint egyre hihetőbb, hogy Stephen Paddock az Iszlám Állam terroristája lehetett. 2017. 10. 05. Forrás: https://444.hu/2017/10/05/a-new-york-times-szakertoje-szerintegyre-hihetobb-hogy-stephen-paddock-az-iszlam-allam-terroristaja-lehetett (2017. 12. 13.)

\section{Jogforrások}

1978. évi IV. törvény a Büntető Törvénykönyvről.

1997. évi ENSZ-egyezmény a robbantásos terrorizmus visszaszorításáról.

1998. évi IV. törvény a személy-, vagyonvédelmi és magánnyomozói kamaráról.

1999. évi ENSZ-egyezmény a terrorizmus finanszírozásának visszaszorításáról.

2001. évi LXXXIII. törvény a terrorizmus elleni küzdelemről, a pénzmosás megakadályozásáról szóló rendelkezések szigorításáról, valamint az egyes korlátozó intézkedések elrendeléséről

2002. évi XXV. törvény a robbantásos terrorizmus visszaszorításáról, New Yorkban, az Egyesült Nemzetek Közgyúlésének 52. ülésszakán, 1997. december 15-én elfogadott nemzetközi egyezmény kihirdetéséről.

2005. évi CXXXIII. törvény a személy- és vagyonvédelmi, magánnyomozói tevékenység szabályairól. 2007. évi XXVII. törvény a Büntető Törvénykönyvről szóló 1978. évi IV. törvény és más büntetőjogi tárgyú törvények módosításáról.

2009. évi LXXX. törvény a Büntető Törvénykönyvről szóló 1978. évi IV. törvény módosításáról.

2012. évi C. törvény a Büntető Törvénykönyvről.

30/1990. (XII. 15.) AB határozat.

A Tanács kerethatározata (2002. június 13.) a terrorizmus elleni küzdelemről (2002/475/IB).

Magyarország Alaptörvénye. 


\section{ABSTRACT}

\section{The Current Context of the Relationship between Private Security and Acts of Terrorism} FÁBIÁN Péter

It is hardly an exaggeration to say that terror has become part of our daily lives and we must rethink what we have previously considered acts of terror. It is becoming more and more commonplace to hear news about suicide bombers, fanatics who blow themselves up at railway stations or on the subway. This media coverage, while primarily, on the one hand, concerned with the victims, the dead, the injured and the traumatised, also serves to highlight the leniency with which some of the perpetrators, terrorists, have been treated by the legal system and the lack of deterrence the current criminal law provides.

One of the major lessons of the past two decades is that states are unable to guarantee security through civil bodies. It is therefore appropriate to consider whether, and to what extent citizens, citizens' organizations or even economic operators can be involved in the maintenance of public security. "Without community activity, the state can never fulfil its vocation", points out Zsolt Németh. "Public security", he stresses, "is a collective social product, far from being a product of law enforcement activity".

In my study, I analyse the concept of terrorism, the forms in which it presents itself, the criminal law pertaining to acts of terror, and then I examine the issues raised with regards to the area of private security.

Keywords: terrorism, private security 